
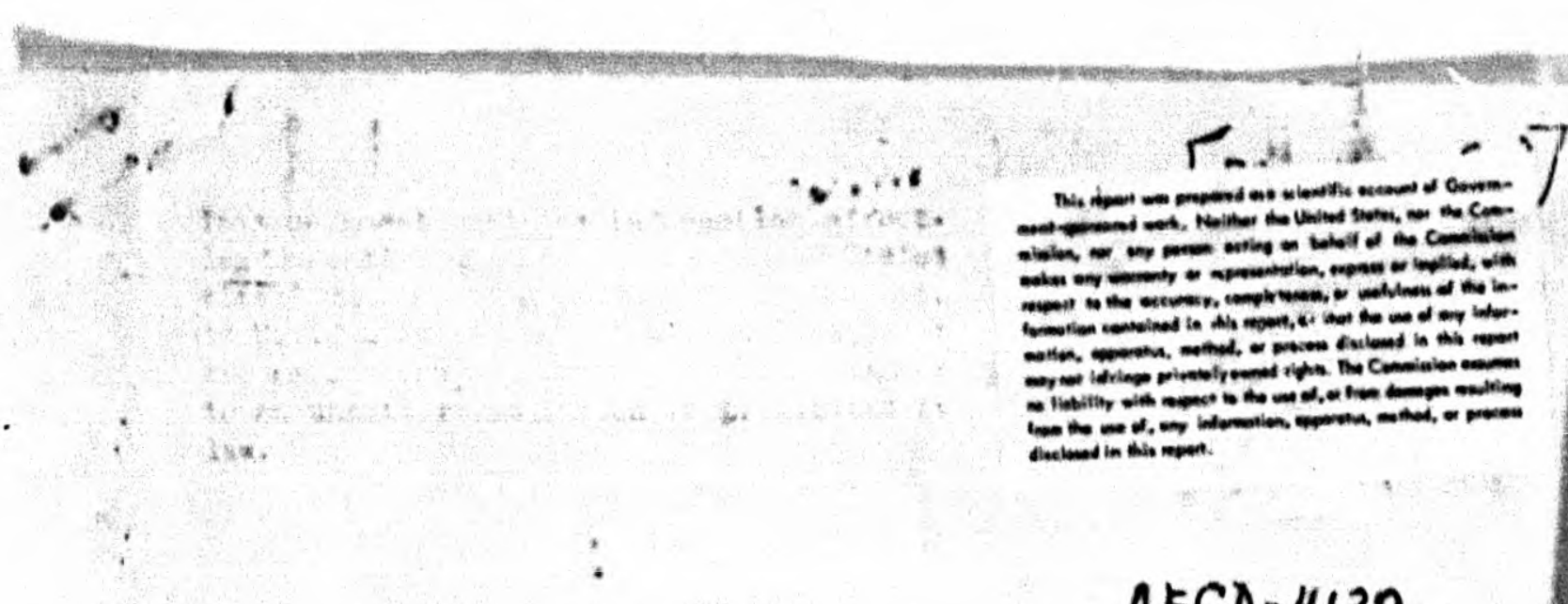

\title{
AECD -4139
}

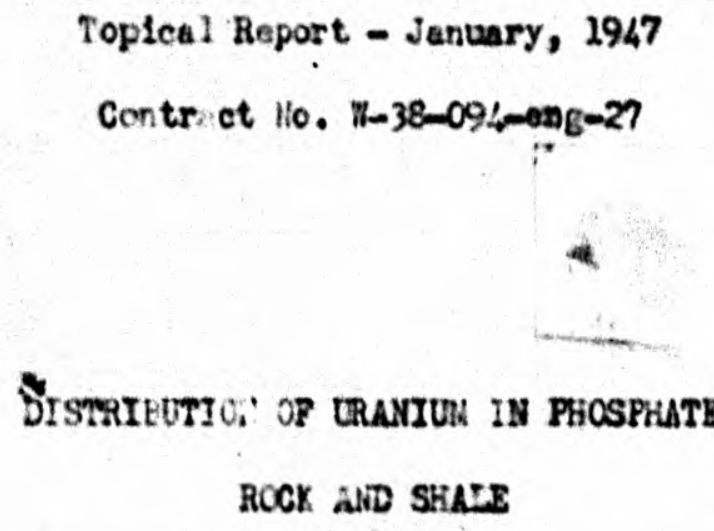

ROCK AND SHATE

\section{Propared bys Iver Igel arud John D. Sullivan Adan Tesner}

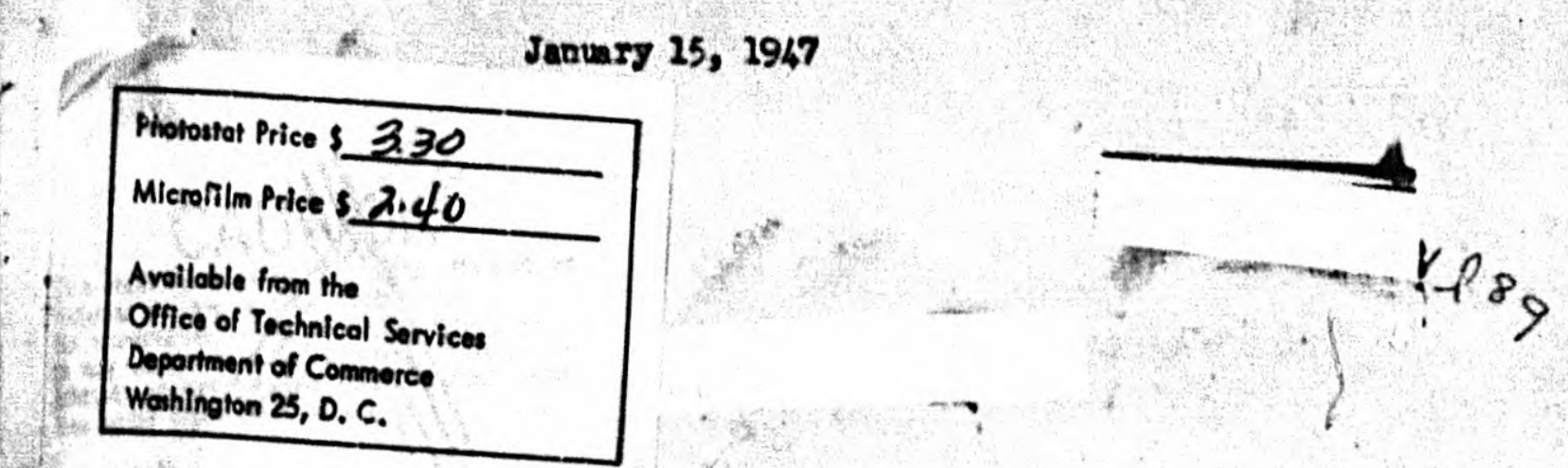


TARLE of Colroirs

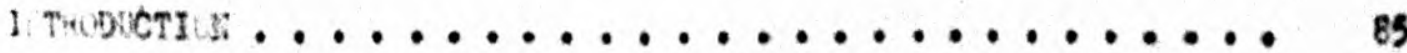

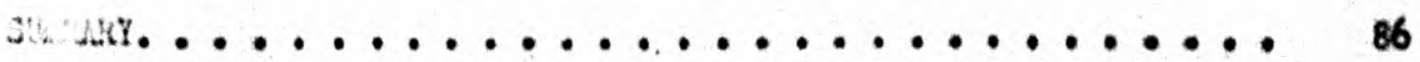

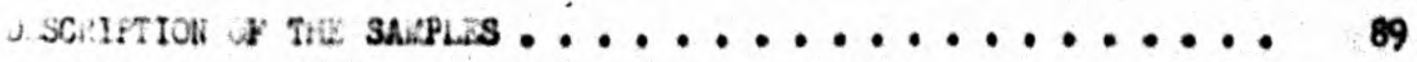

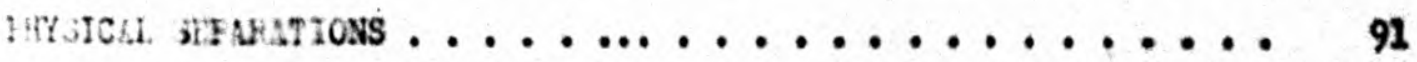

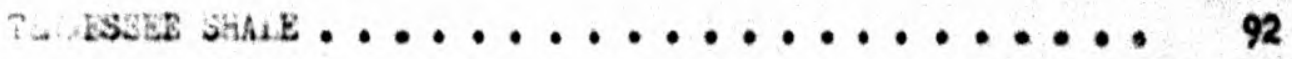

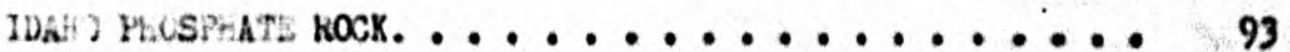

IASHLD FLGLIDA PSB LE PYOSPHATE . . . . . . . . 93

Color of Pobblos ............... 93

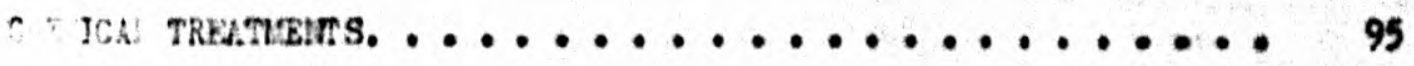

TEMESSE SHALE ................. 9

IDAHO PHOSPHATE ROCK. ................ 9

ILSISD FLORIDA PEBELE PHOSTHATE ............

988 


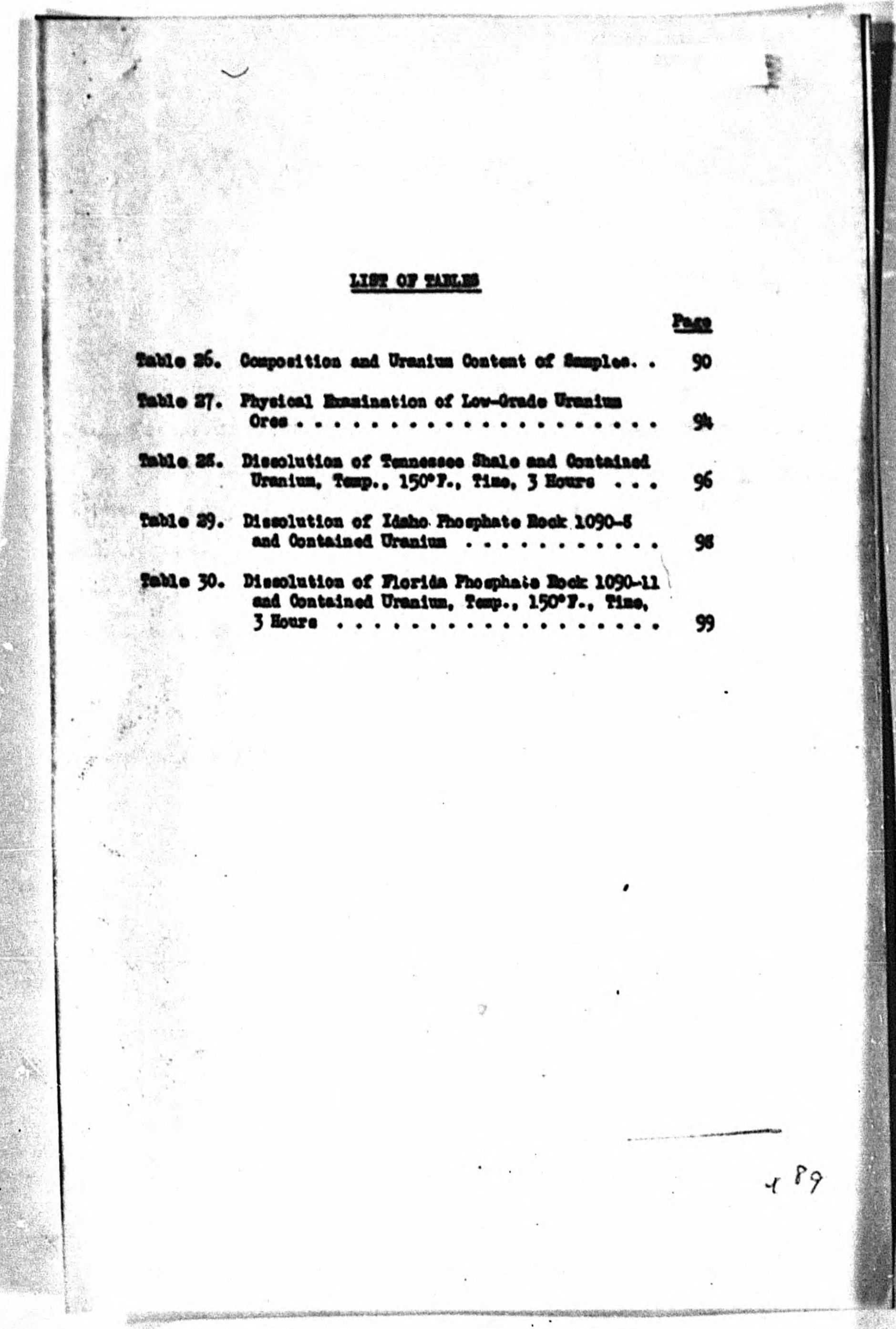




\section{Domopucrion}

The purpose of this report is to eunearise come of the informetica obtalned to date on the diatribution of the uranium in the alnerel phases of the phosphate rooks and shale. Virtually no nen informatioa le strex. over that contained in the respeotive wonthis reports beginning Soptember 30 , 1946, and wat will be Included in that for January 31, 1947. In ead1tioned purpose is to correlate the ore-dressing and chomical-diesolution stvalea on uranium diatribution in the "ores" being atudiod.

As this report is a sumery of Information avallable elsentere. details of procedure, ete., are not inciuded. The Interested reader 10 referrod to monthly reports for such detalls. 


\section{$-86$}

Topleal Report - Jenus ry, 1947

Contraet Ho. IB-38m-09/unge-27

\section{sunger}

Data sre ausarized on the distribution of urendu in varlous phases of one ahale and two phosphete rooks. / The "ores" wore exalined by physioal means, such as float-and-aink with heavy Ilquids, and by chenlcal dievolution studiea. The findings of the tro mothods agree.

The shale and the phosphate rock wust bo considered coperately becouse the fIndings vere difeerent."/A floatmand-aink soparation of renneeseo shais resulted in $93.4 \%$ perceant of the woight under 2.65 ap. Gr., with the resainder about equally distributed between 2.65 to 2.95 and over 2.95 . $u$ The uranius analysis of the under 2.65 product was virtually the seve as the head anple. In the alnor weight fractions, the ureaiva conteat wae about bals that of the heads in the over 2,95 rrection and about teleo tho heads in the interaediate fraction.

$\Lambda$ aegnotio roast followed by a ngnetio separation did not disclose coneontration of uranliu in ofther the magnotic or the nosmeagnotlo partions. 7

A rroth Nlotation concentrated the organio matter in the overflow, U bit urensule wes not ooncentrated in either product.

Tros the chemical aide it, was posstble to dissolve es high as $67 \%$ peceent of the weanles from the shele with nog-oxdaistag eelds with d5esolut 1 un of less than $>10 \%$ poserent of the welght of the whale. Oxdaising acide were no bore offioacious than now-exidising ones in extracting the on 
Top1cal Report - January, 1947

Contract No. $\mathbb{N}-38-094-\mathrm{eng}-27$

uranlua, but there was slightly more attack on the ehale. per eed Howover, the eaximum welcht peroentace of the shale dissolved oven with oxidising agents was only 13.5 .

To effect additional urenius extraction it is necessary to ecucompono the silicates. 2

Dith Idaho phosphate rock (1090-8) a float-and-sink oeparation resulted in a weight distribution as followas

$\begin{array}{lr}\text { Sne are } & \text { 1t. } \\ \text { Over } 2.71 & 79.1 \\ 2.65 \text { to } 2.71 & 7.0 \\ \text { Onder } 2.65 & 9.9\end{array}$

The uranium anelysis showed that the over 2.71 op. Er. portion, which wae substantlally phosphate contained about the percentage as the hesds sanple. The quarta fractions wore low in urenium.

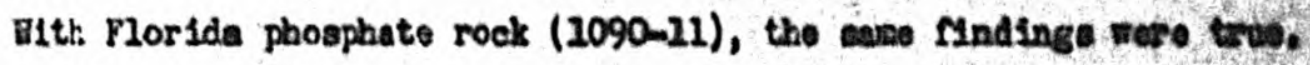
The high-gravity frection contalned about the percentage of urealua os the heads whereas the 10w-gravity portione wore substantially lowere The content, however, was higher in both gravdty ranges than in the case of Idaho rock.

Pebbles were soparated by color Into 5 elasses white, brom, blick, yellow and red. The first three were largely phoophate and the last two vere $20 \mathrm{z}$ In phosphate and high in carbonates. Tho wraniura coatent of the first three was substantially the seme as the overall hoeds enelyallo. The last two were loi in uraniva. 


\section{-88- \\ Topical heyort - January, 1947 \\ Contr: ct: $110.13-38-094$-ene-27}

- \%).

In the chomical-diecolution studies, with ncp-oxitistr $\ell$ eclds, such as sulphonde siffi, the parcentsge of the urentua dissolved was roughly proportinnal to the percentege of the totel rock dissolved. No trouble wes experienced in extracting 85 to 90 fyecoent or even sore of the unentum. With Idaho phosphate rock the frding was the same of 1.e., the percentage of the uraniua dissolved was proportional to the percentage of the rock dissolved. 1 Extrsctions of $98 /$ pep-eent of the trzentur were cbtained vith non-oxidizing acids. / w

These studies betr out the ecnclusion thot in the phosphate rook the urenius is directly essociated with the phosphate minerals, Other chemical stuiles not reported in detall here further hear out that it en a defiolency of acid is enployed the percentace of uranlun extracted is etill propertionsl to the percentage of the rock dissolved, 


\section{$-69$ \\ Topical Report - Januery, 1947 \\ Contract Ho. in-38-094-eng-27}

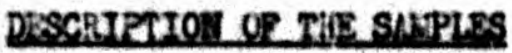

Partial chesical ans yses incluiling uranius contents deterained by chenical end b-count anaiyses are given in Table 26 for one of the shales and two phosphete rocks described in this report. No. $1090-4$ was nct anaiyzed except for urantum but is probably similar to No, 1090-1. For 1Hentification of nasples, surce, etc., seo Table 1, page 2, roport of Sontenber $30,1946$.

$$
8989
$$




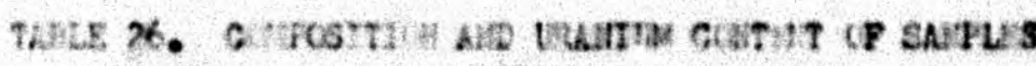

\begin{tabular}{|c|c|c|c|c|c|c|c|c|c|c|c|c|}
\hline the & & & & & & Eopest & a 8 & & & & D. & \\
\hline$\frac{\text { Sennic }}{\text { te. }}$ & $\frac{V_{0}}{V_{2} e_{6} s_{2}}$ & $\begin{array}{l}\text { oricin } \\
\text { (1) }\end{array}$ & $\mathrm{C}_{\mathrm{AO}}$ & $\overrightarrow{\mathrm{P}} \mathrm{e}_{2} \mathrm{O}_{3}$ & $\begin{array}{l}\mathrm{Al}_{2} \mathrm{O}_{3} \\
12]^{2}\end{array}$ & $\mathrm{P}_{2} \mathrm{O}_{5}$ & $\mathrm{SIO}_{2}$ & 7 & $\mathrm{CO}_{2}$ & $\begin{array}{l}201 \\
131\end{array}$ & Chen. & E-Count \\
\hline $10 \times 0-1$ & $5 x-15<-46$ & tS & 1.46 & 10.7 & 12.6 & - & 46.0 & - & 0.2 & 23.4 & 0.011 & 0,0080 \\
\hline $1090-6$ & $s 10 c-46$ & Ts & - & - & - & - & - & - & - & - & 0.008 & 0.0065 \\
\hline $1090-8$ & $3-2$ & $I P R$ & 38.3 & 1.63 & 2.62 & 29.7 & 12.0 & 2.77 & 1.57 & 8.7 & 0.013 & $0.012_{8}$ \\
\hline $1090-11$ & FF 39X & FPR & 44.5 & 1.27 & i. 19 & 31.3 & 7.14 & 3.66 & 4.42 & 7.4 & 0.020 & $0.021_{8}$ \\
\hline
\end{tabular}

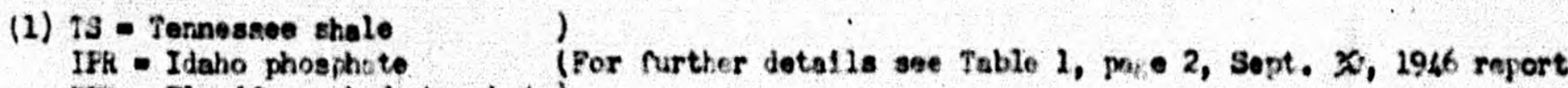

FFH - Florida washed phosphate)

(2) Inc wies $\mathrm{THO}_{2}, \mathrm{ZrC}_{2}$, to

(3) Loss on Ignition at $1000^{\circ} \mathrm{C}$.
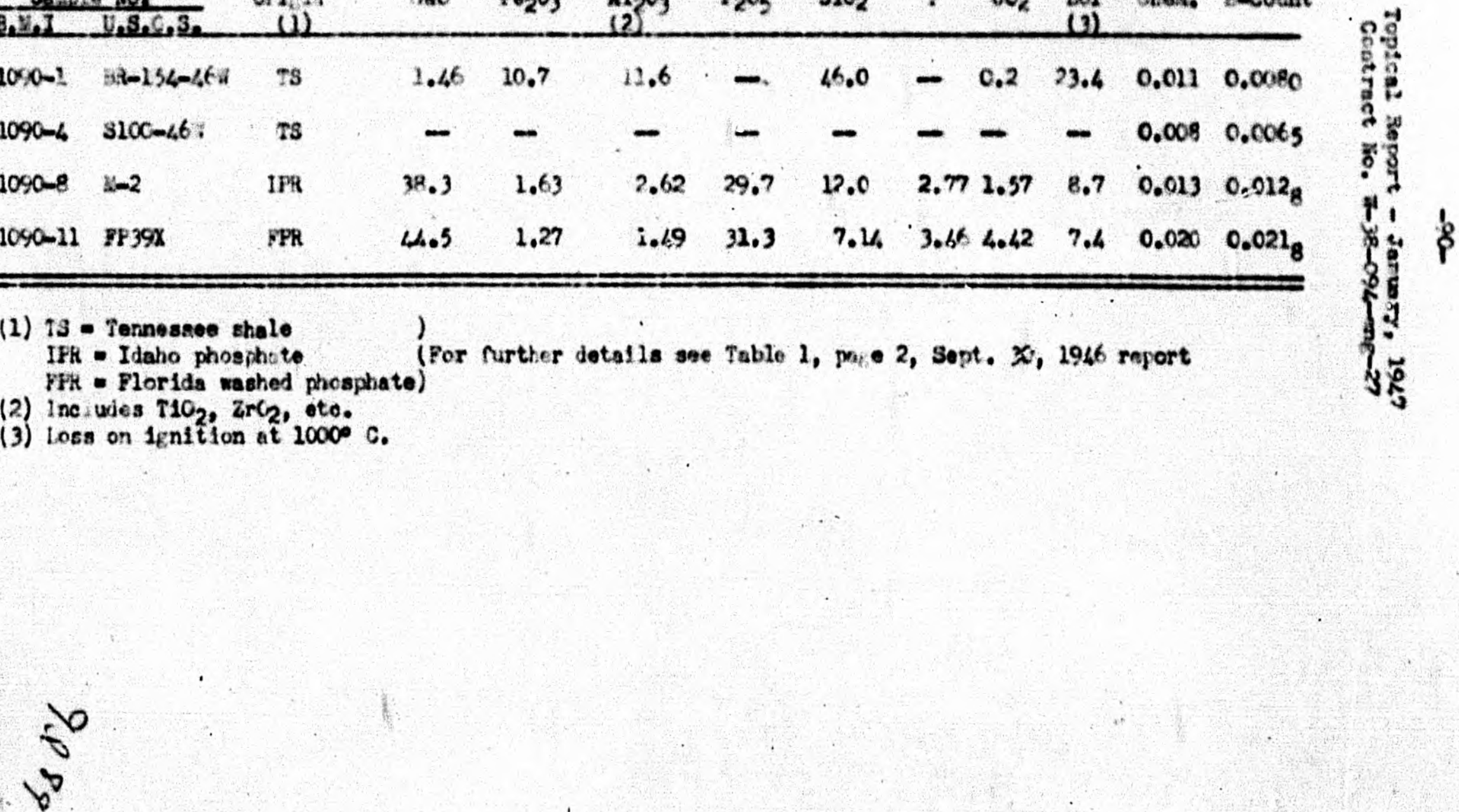
Topical Report - Jamuary, 1947 ;

Contract No. $*-38-094-e n g-27$

\section{PHPSICLL SAPARATISAS}

Separations of the phases were made by physical meanis, ouch as Ilostmand-sink, and the uranium contents were obteined by wet chomical analyses or by the Geifer counter method. The results of various separations with enajgses of the products are sumnarized in Table 27. 
Topleal Report - Jesuasy, 1947

Contraet Bo. V-38-094-enc-a7

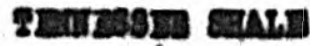

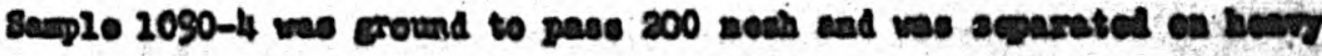

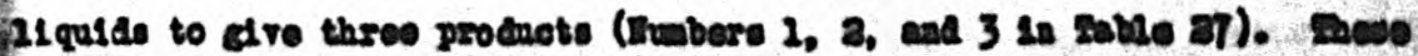

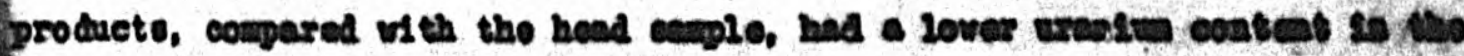

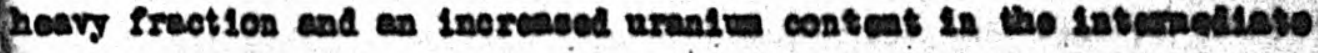

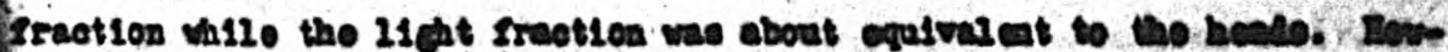
the

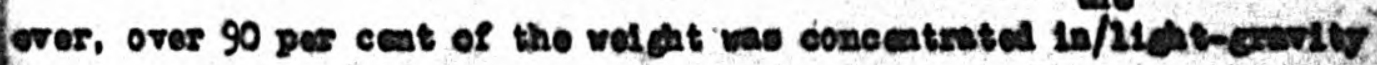
fraction.

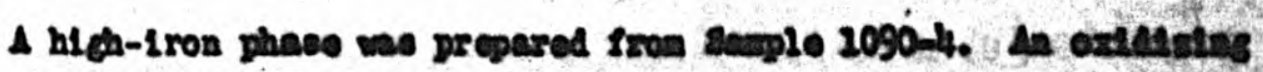

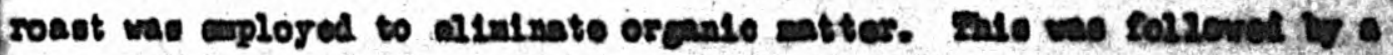

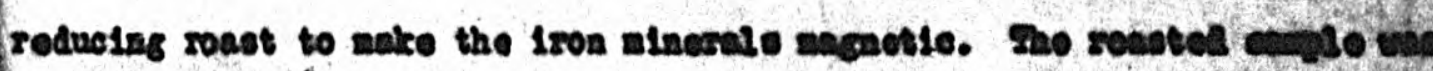

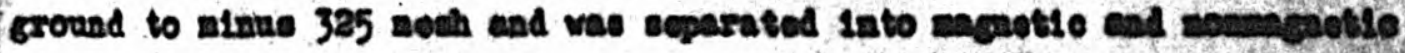

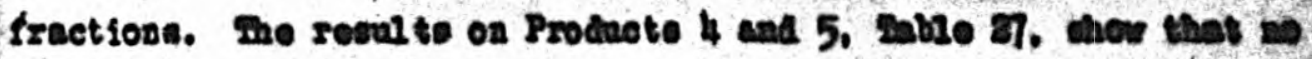

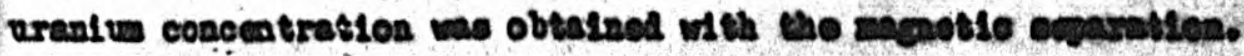

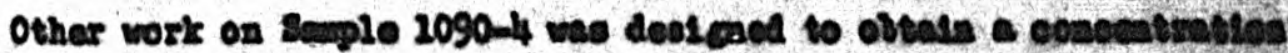

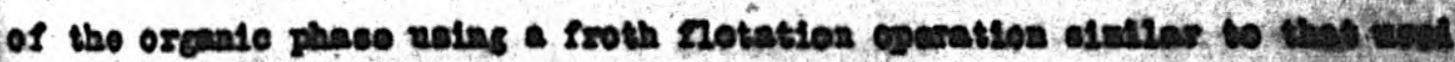

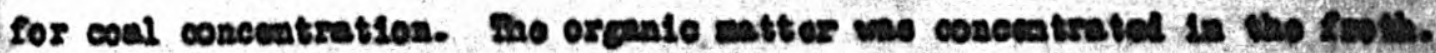

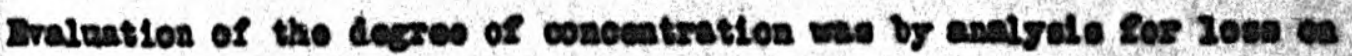

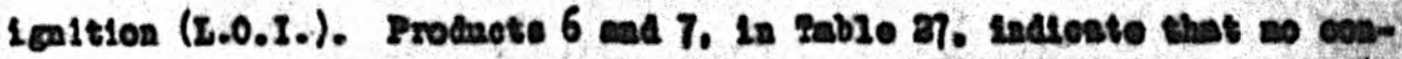

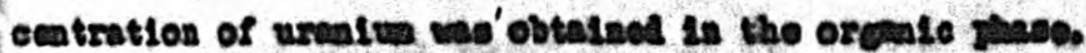




\section{Topleal Roport - Jameary, 1947}

Contrect Bo. V-38-094-enc-27

\section{IDARO FROMTAFS DOCS}

On Semplo 1090-8 a concentratlon of the quasts phace was doelred. In order to obtaln a good hearg-11quile ecparatidn between the phoophate

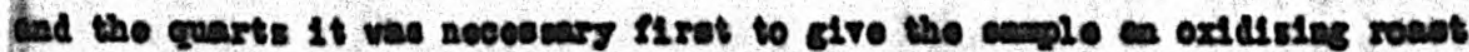

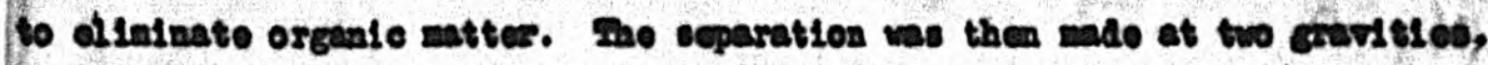

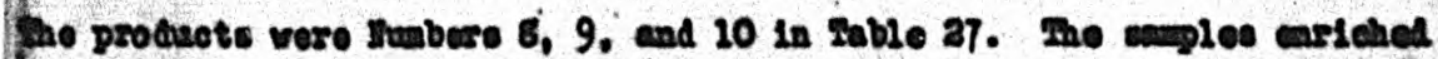
in quarts conotituting about 17 per ceit of tho woldot were cubotentially

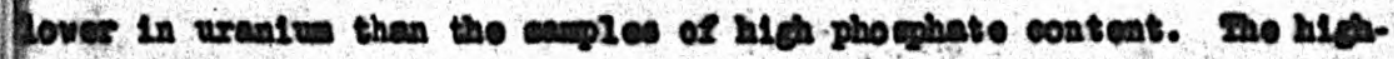

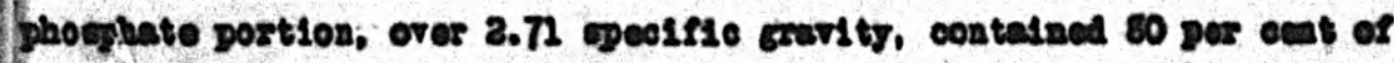

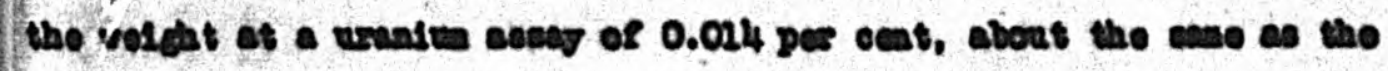
ortedinat orë.

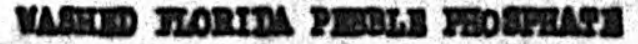

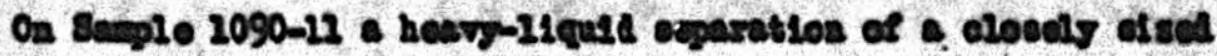
gremules frection cave a reaconebly cood quarts concentration, wo chow

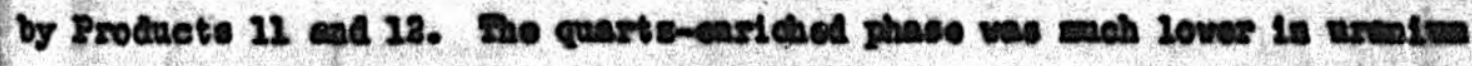

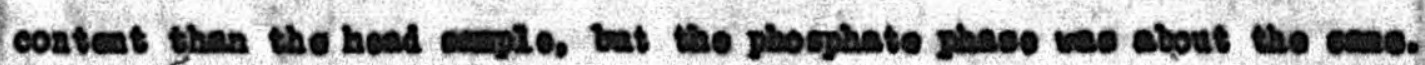<smiles>[CH]1[CH]C1</smiles>

\section{Qoler of robstes}

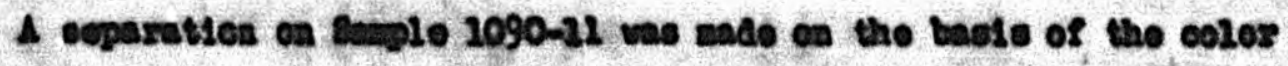
of tho pobblee, Do producte ere Mated in sablo 27 a Ilabibers 13 to 27.

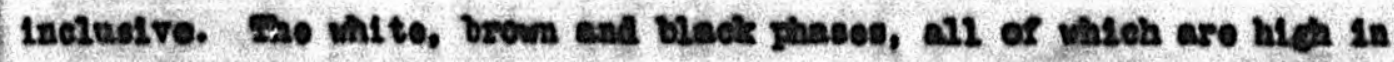
phomphate content, have a uranin conteat about the eage es the hond exple 


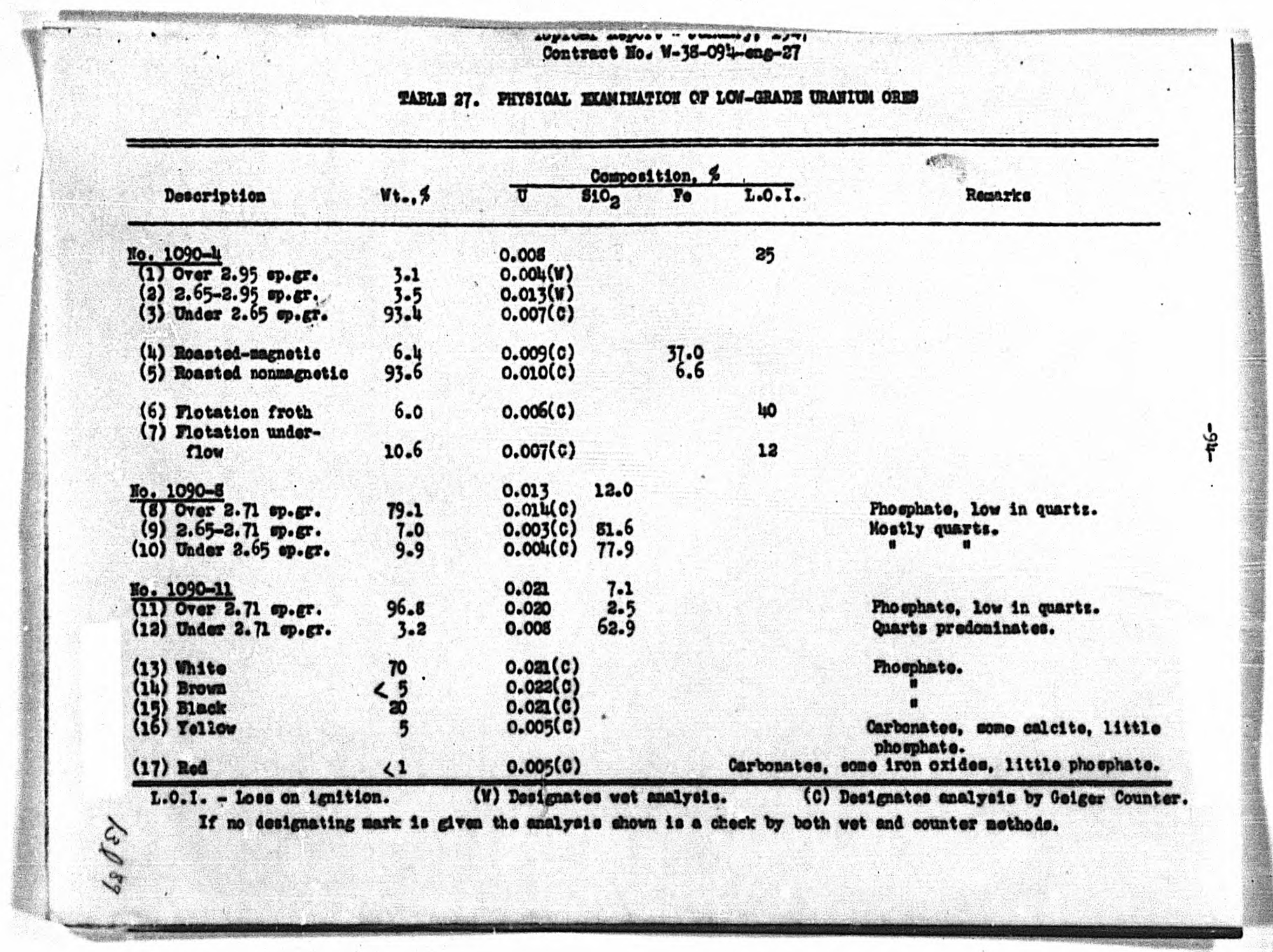




\section{$-35-$ \\ Topl cal Roport - January, 1947 \\ Contract Ho. W-38-094-eas-27}

wh1le the yollow and rod phaces, which are lov in phoophato and hich in ear bonate content, aro low in uranlum.

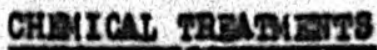

The chemical treatmente conal ot ed of leaching then with varloue rear Gents and, In the case of the phoophate rock, making superphocphate and leaching this wi th water. Becopt where otherwise noted all analyelo wero chenlcal. Because chemical analyole wore only for the ajor conetituento the amounts given under Reagent, \& of Theoretical 10 only approximato. It Io based on the best eatimate of total bacio in the semple.

\section{TanEs: SRAT}

The resul to of leaching two sinilar Tennessee thal es with varlous oolutlone are ohown In rable 28.

A feature of the teats is the reletivoly laree esount of urablus that wae diseolved with reletively enall diseolution of the ohale 1tecls. The greateat esount of hhale diseolved, without a otrong oxdelatng eseat wheh ae nitric ac1d, wae 9.6 per cent vith $1: 4$ eusphurle eete ea-109044. About 30 per cent of the uraniun was dieeolved. Wlth $1: 2$ hydrochlorte seld the roek diseolvod was 6.25 and 8.6 per cent for Samples $1090-1$ and 1090-4, respectively, and the corregponding uranium extractione vere 57 and 67 per cent respoctively.

vitric acia diseolved nore chale, probably because of oxidation of organle mattor, bat disselved no more uranium. Mild oxtdising wixturee or alkall carbonates wero least offoctivo. 


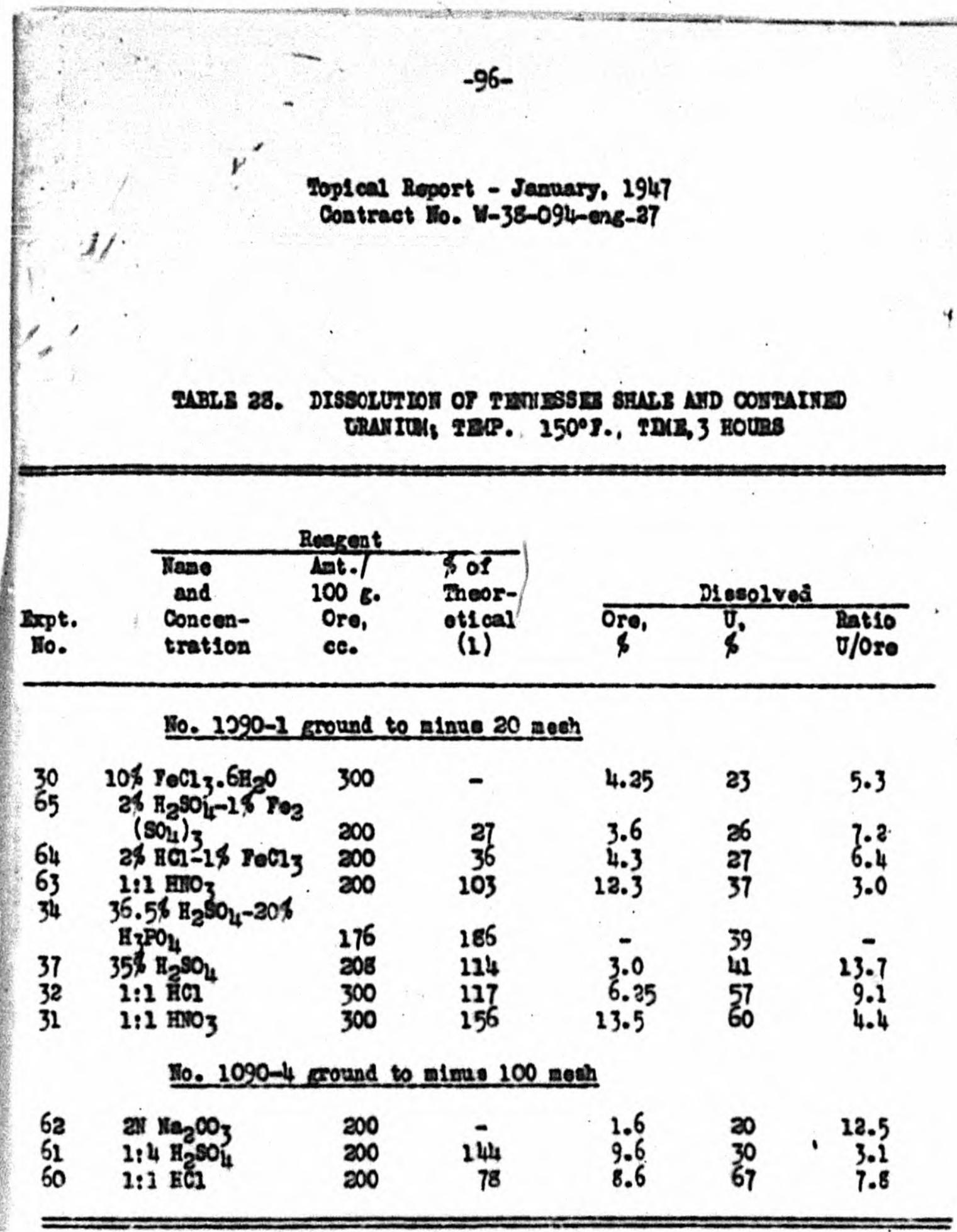

(1) Based on total bases prosent.

Approximate. 
The renalning 30 to 40 per cent of the uranium ald not seen emenablo to extraction without more drastic attack on oflicates:

The finenese of grinding within the narrow range studied secmed to beve 11 ttio of foct.

\section{IDAHO PHOSPRATE BOCS}

The resul ts on Idato phoophate rock ground to winus 100 weeth are ohown in Table 29.

The two most striking feature of these data are that ( 1 ) the anount of uranlus dissolved was roughly proportional to the asount of rock diseol ved and (2) nearly all, 85 to 90 per cent, of tho total uranlua was soluble in nonoxidizing acid colutions. These resulte indicate two thinge: (1) the uranium Is uniforaly dieseninated throuch that part of the rock mase diseolved by the reagento and (2) the uranlum probably is almost entiroly in the hexaval ent condition.

The extent of total dissolution of the ore was uneertaln in nose instances there oulphurle acld was used, because of fornation of Copoum. The asount of realdual phosphate vae used ae a tentative index.

\section{WASH ED FLORIDA PEBBLE PLOSPEATE}

The data obtained with Forida rock are glven in Table 30.

The resarks made about Idaho phoophate apply to this roak. The percentage extraction of urantum was in proportion to the percentage of the rock d1soolved and the uranium wa almost wholly, 98 por cent, soluble in a nonoxldisine acid. 
Topiceil Heport - January, 1947

Contract Ilo. $1-58-094 m-e_{6-27}$

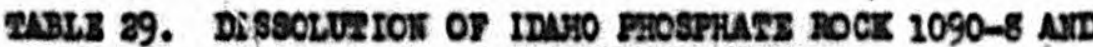
Comatris unarto:

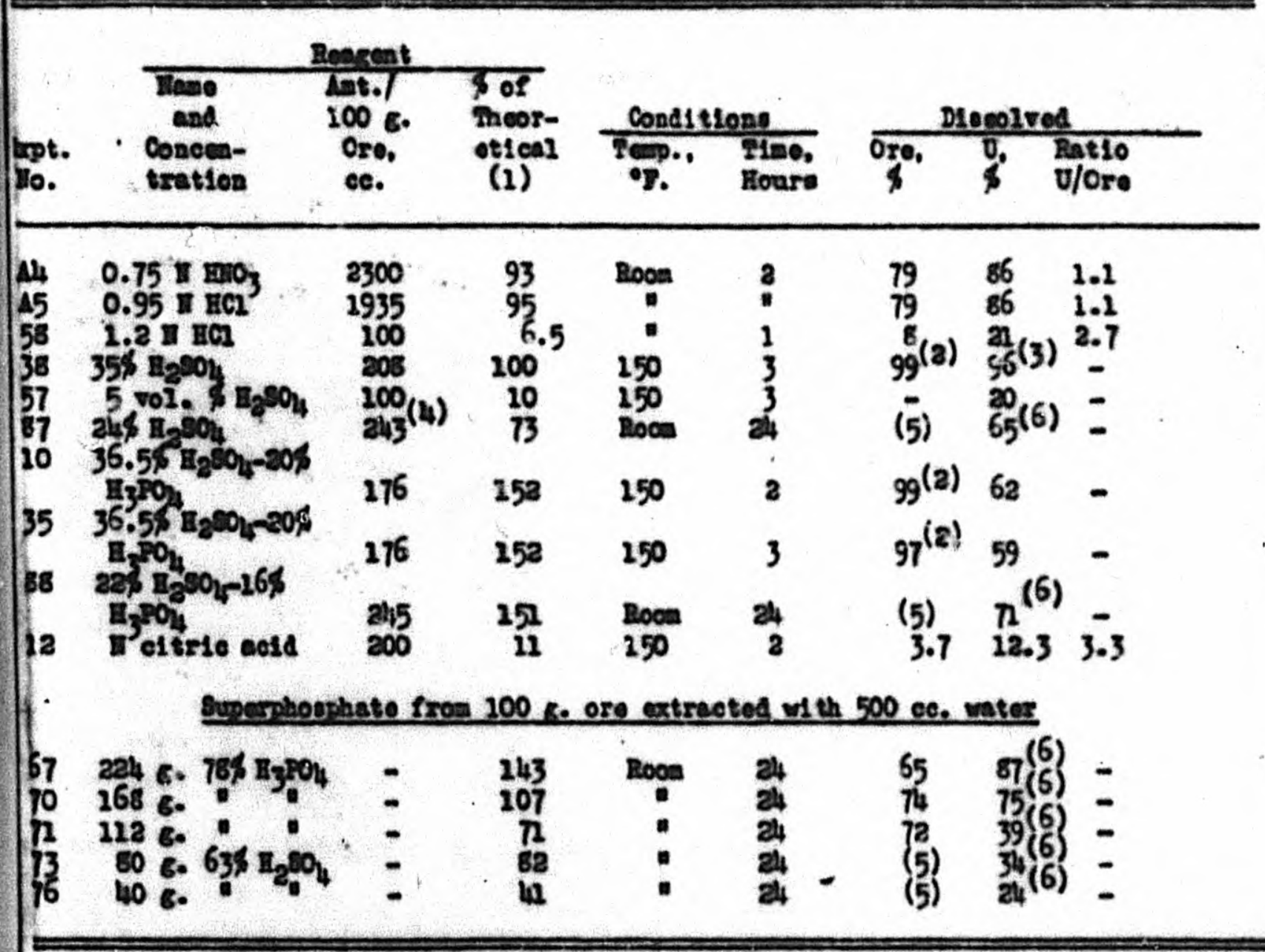
(1) Based on total beses. Approxdasto.
(2) Baeed on reeidual phoophate after leaching.
(3) Boing recheoked.
(4) Culeinod oro - 91.2 gremo.
(5) Iot yot averiabio.
(6) Inalyolo by 8 -covant. 
$\therefore \because$

$\rightarrow$

Topleal Roport - January, 1947

Coatract $\mathrm{D}_{0}$. W-38-094-enc-27

RABLE 30. DISSOLUTIOY OY FOEIAA PFOSFHATS DOCX 1090-11 AID

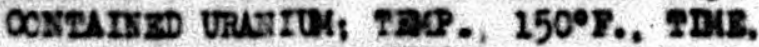

\begin{tabular}{|c|c|c|c|c|c|c|}
\hline \multirow[b]{2}{*}{$\begin{array}{l}\text { 3xpt. } \\
\text { No. }\end{array}$} & \multirow{2}{*}{$\begin{array}{l}\text { Fea } \\
\text { end } \\
\text { Concen- } \\
\text { tretton }\end{array}$} & \multirow{2}{*}{$\begin{array}{c}\text { Reazent } \\
100 \text {. } \\
0 . \\
\text { re. } \\
\mathrm{ce} .\end{array}$} & \multirow{2}{*}{$\begin{array}{l}\text { por } \\
\text { Theor- } \\
\text { etleal } \\
\text { (1) }\end{array}$} & \multicolumn{3}{|c|}{ Dieselrod } \\
\hline & & & & $\underset{\$}{\text { Ore. }}$ & 8 & $\begin{array}{l}\text { Ratio } \\
\text { 0/0 }\end{array}$ \\
\hline 33 & $106 \mathrm{~F}^{\circ} \mathrm{Cl}_{3} \cdot 6 \mathrm{H}_{2} \mathrm{O}$ & 300 & - & - & 9 & - \\
\hline 36 & $\begin{array}{l}35.56 \mathrm{~B}_{2} \mathrm{SO}_{4}-206 \\
\mathrm{~B}_{3} \mathrm{FO}_{4}\end{array}$ & 176 & 147 & $76^{(2)}$ & 38 & - \\
\hline 39 & $356 \mathrm{H}_{2} \mathrm{SC}_{4}$ & 208 & 96.5 & $73^{(2)}$ & 4 & - \\
\hline 25 & 1:1 หอ1 & 300 & 92.5 & 90 & 98 & 1.1 \\
\hline 29 & $1: 1 \mathrm{SEO}_{3}$ & 300 & 121 & 95 & 99 & 2.05 \\
\hline
\end{tabular}

(1) Based on total bases present. Approxieato.

(a) Based on asalyois for residual phosphate. 